\title{
Effect of Minicutting Length and Leaf Area Reduction on Growth and Nutritional Status of Eucalypt Propagules
}

\author{
Reynaldo Campos Santana, ${ }^{1}$ Sula Janaina Oliveira Fernandes, ${ }^{1}$ Miranda Titon, ${ }^{1}$ \\ Aloisio Xavier, ${ }^{2}$ Priscila Fernandes de Souza, ${ }^{1}$ and Nairam Felix Barros Filho ${ }^{3}$ \\ ${ }^{1}$ Department of Forestry, Federal University of the Valleys of Jequitinhonha and Mucuri, Campus Diamantina, \\ 39100-000 Diamantina, MG, Brazil \\ ${ }^{2}$ Department of Forestry, Federal University of Viçosa, Campus UFV, 36570-000 Viçosa, MG, Brazil \\ ${ }^{3}$ Department of Soil, Federal University of Viçosa, Campus UFV, 36570-000 Viçosa, MG, Brazil
}

Correspondence should be addressed to Priscila Fernandes de Souza; souza.fernandes.p@gmail.com

Received 13 May 2013; Accepted 2 July 2013

Academic Editors: J. Kaitera, T. L. Noland, and H. Zeng

Copyright (C) 2013 Reynaldo Campos Santana et al. This is an open access article distributed under the Creative Commons Attribution License, which permits unrestricted use, distribution, and reproduction in any medium, provided the original work is properly cited.

\begin{abstract}
Significant improvements to the technique of minicutting Eucalyptus clones have been reported in the literature. However, despite these recent efforts, studies addressing the proper size of minicuttings and the reduction of leaf area have not been well explored. Thus, the present study had the objective of evaluating the effects of the length of the minicuttings and the leaf area reduction on the growth and nutritional condition of Eucalyptus urophylla during propagation. The experiment was conducted for 90 days in the Plantar Reforestation Co. Nursery in the municipality of Curvelo, MG, using a randomized block design with 4 replicates in a $4 \times 2 \times 2$ factorial arrangement. The effects of 4 lengths of minicuttings $(4,6,8$, and $10 \mathrm{~cm}), 2$ levels of leaf area reductions $(0$ and 50\%), and 2 commercial clones were studied. The length of the minicuttings and the reduction of leaf area did not affect the nutritional status of the leaves, nor did the length affect the quality of the plants at the age of 90 days. The results indicate that it is unnecessary to reduce the leaf area for Eucalyptus propagation.
\end{abstract}

\section{Introduction}

The propagation of plants by minicuttings is a widely used technique employed for the production of Eucalyptus seedlings and has been published in various media. The scientific literature has shown that much of the success of this technique depends on the selection of the appropriate propagules and proper silvicultural practices, which aim to ensure efficiency in the production of high-quality seedlings [1].

In the production process, nurseries customarily produce clonal Eucalyptus plants with minicuttings ranging in size from 4 to $10 \mathrm{~cm}$, with at least two pairs of leaves of reduced leaf area $[2,3]$. The basic procedure for the reduction of leaf area on minicuttings used in most nurseries today is virtually the same as was used in plant propagation by cuttings (macrocuttings) in the 1980s and 1990s, although the vegetative propagules of minicuttings are smaller and more juvenile compared with macrocuttings. In addition, irrigation systems in nurseries have evolved significantly in recent years [4].

The retention of leaves or parts of leaves on the stem is necessary for the production of auxins and rooting cofactors that are translocated to the cutting base and promote rooting $[5,6]$. Lima et al. [7] evaluated the effect of a reduction in leaf cuttings of Mikania spp. (Guaco) and found that an increase in leaf area positively influenced the percentage of rooting and the survival of the plants. Reuveni and Raviv [8] observed a higher percentage of rooting for avocado cuttings (Persea americana Mill.) that retained leaves and attributed this result to the elevation of sucrose at the base of the cuttings.

Within this context, this study aimed to evaluate the effects of the length of the cutting and reduced leaf area on the growth and nutrient content in Eucalyptus urophylla during propagation. 


\section{Materials and Methods}

The experiment was conducted between July and October 2008 at the Plantar Reforestation Company Nursery in Curvelo, MG. Seedlings were grown for 90 days using the company's two commercial clones (hybrids of Eucalyptus urophylla ST Blake). A randomized block design was employed, with four replications in a $4 \times 2 \times 2$ factorial design. The effects of four sizes of apical minicuttings, S (S: 4, 6, 8, and $10 \mathrm{~cm}$ ), two levels of leaf reduction (LR; 0 and $50 \%$ ), and two clones ( $\mathrm{Cl}$ and $\mathrm{C} 2)$ were studied. The experimental unit consisted of 33 central plants in trays of 190 cells, for a total of 2,112 seedlings measured. The other seedling trays received the same treatment and were considered "border" plants.

The reductions in leaf area were obtained by crosssectioning apical leaf minicuttings that had at least one pair of fully formed leaves. The LR and S were performed by the nursery staff who had been trained to perform these steps in the proportions and sizes recommended. Afterward, the minicuttings were staked to a depth of $2 \mathrm{~cm}$ in the center of polypropylene tubes $(125 \mathrm{~mm}$ and a capacity of $55 \mathrm{~cm}^{3}$ ). These tubes contained a substrate composed of $40 \%$ middle-sized grain vermiculite, $40 \%$ scorched rice husk fiber, and $20 \%$ coconut husk fiber. Then, $2.4 \mathrm{~kg} / \mathrm{m}^{3}$ of slowrelease fertilizer was applied $\left(13 \% \mathrm{~N}, 6 \% \mathrm{P}_{2} \mathrm{O}_{5}, 16 \% \mathrm{~K}_{2} \mathrm{O}\right.$, $1.4 \% \mathrm{Mg}, 10 \% \mathrm{~S}, 0.26 \% \mathrm{Fe}, 0.02 \% \mathrm{~B}, 0.05 \% \mathrm{Cu}, 0.06 \% \mathrm{Mn}$, and $0.015 \% \mathrm{Mo}$ ).

The seedlings remained for 15 days in the greenhouse and received misting as the exclusive irrigation to maintain a humidity above $70 \%$. The seedlings were transferred to a shade house for 15 days and received $4 \mathrm{~mL}$ of fertigation per seedling per day (50\% in the morning and $50 \%$ in the afternoon). The seedlings were then transferred to a growth area in the open, with only $50 \%$ of tray cells filled with seedlings, and were treated with $6 \mathrm{ml}$ of fertigation per day for 90 days. At all stages of growth, the experiment was conducted alongside the regular seedling production process at the company.

The fertigation solution was composed of the following: $5.5 \mathrm{~kg}$ of $\mathrm{Ca}\left(\mathrm{NO}_{3}\right)_{2}, 1.5 \mathrm{~kg}$ of $\mathrm{MgSO}_{4}, 2.63 \mathrm{~kg}$ of $\mathrm{KCl}, 0.9 \mathrm{~kg}$ of $\mathrm{NH}_{4} \mathrm{H}_{2} \mathrm{PO}_{4}, 2.0 \mathrm{~kg}$ of $\mathrm{NH}_{4} \mathrm{SO}_{4}, 0.035 \mathrm{~kg} \mathrm{H}_{3} \mathrm{BO}_{3} 0.004 \mathrm{~kg}$ of $\mathrm{CuSO}_{4}, 0.015 \mathrm{~kg}$ of $\mathrm{ZnSO}_{4}, 0.017 \mathrm{~kg}$ of $\mathrm{MnSO}_{4}, 0.02 \mathrm{~kg}$ of FeEDTA (10\%), and $2.5 \mathrm{~kg}$ of single superphosphate per 1,000 liters of water.

At 45 days after planting, the survival rate (SR; \% of live cuttings with a developed root system) and the shoot height $(\mathrm{SH}$, in $\mathrm{cm})$ of all 33 of the plants in the experimental unit were measured. Cuttings featuring green stems without the development of roots were considered dead plants.

After a total of 90 days, the following variables were measured for all of the plants of the experimental units: the SR (\%); $\mathrm{SH}(\mathrm{cm})$; stem base diameter (SBD, $\mathrm{mm}$ ); shoot dry matter (SDM, g/plant); root dry matter (RDM, g/plant); total dry matter $(\mathrm{TDM}=\mathrm{SDM}+\mathrm{RDM}$, $\mathrm{g} / \mathrm{plant}) ;$ and leaf concentrations of macro- (dag/kg) and micronutrients $(\mathrm{mg} / \mathrm{kg})$. Indexes that express the quality of seedlings were calculated according to Gomes et al. [10] and the Dickson Quality Index-DQI, as follows:

$$
\mathrm{DQI}=\frac{\mathrm{TDM}(\mathrm{g})}{[\mathrm{SH}(\mathrm{cm}) / \mathrm{SBD}(\mathrm{mm})+\mathrm{SDM}(\mathrm{g}) / \mathrm{RDM}(\mathrm{g})]} .
$$

This index is appointed as good indicator of quality seedlings because it considers in its calculation the strength and balance of distributed biomass [11].

The shoot heights were measured from the tube surface to the apical tip, and the stem base diameters were measured level with the tube. To determine the dry weight, the root system was rinsed in running water to separate the roots from the substrate, and the shoots and roots were dried in a forced-air oven at $65^{\circ} \mathrm{C}$ to a constant weight to produce the SDM and RDM, respectively. The plant material was ground and subjected to nitric-perchloric digestion to perform the chemical analysis [12].

The data were subjected to an analysis of variance, followed by the adjustment of the regression equations using simple linear and quadratic models for the growth as the dependent variable and the length of cutting as the independent variable. The equations were considered valid at a significance level of $5 \%$ for the coefficient of higher order (Alvarez V. and Alvarez 2003). The Tukey's and $F$ tests were used, both at the level of $5 \%$ probability for the comparison of the means. All of the statistical analyses were performed using STATISTICA software, version 10.0 [13].

\section{Results and Discussion}

The ANOVA results for the variables analyzed at 45 days are shown in Table 1. A significant interaction was observed for $\mathrm{C} \times \mathrm{LR}$ for the survival rate and time to separate the effects of the $S$ and LR treatments.

When analyzing the effects of the $\mathrm{C} \times \mathrm{LR}$ interaction separately for clones 1 and 2 , no significant differences were observed after reducing the leaf area for these clones; the same behavior was observed when evaluating the effect of a $50 \%$ reduction of leaf area. The clones behaved differently according to the survival rate, which was assessed in terms of not the reducing leaf area for which clones 1 and 2 showed a survival rate of $95 \%$ and $98 \%$, respectively.

The leaf area reduction was significant for SH. The values with and without leaf area reduction were 9.79 and $8.57 \mathrm{~cm}$, respectively. The largest cuttings reached greater heights (Table 2) in agreement with what was observed by Carvalho Júnior et al. [14]. However, considering that all the cuttings were planted $2 \mathrm{~cm}$ deep in the substrate, when analyzing the increase in height, it was observed that the seedlings produced from the smaller cuttings exhibited greater vitality; that is, they grew to $5.50,4.45$, 3.90 , and $2.87 \mathrm{~cm}$ for $\mathrm{S}$ treatments of $4,6,8$, and $10 \mathrm{~cm}$, respectively.

When evaluating the coefficient of variation between 45 and 90 days, the variation in SR was minimal; for $\mathrm{SH}$, there was a $38 \%$ reduction in the variation. These results indicate that the variations imposed by the treatments tended to decrease with the age of the plant. 
TABLE 1: Summary of the analysis of variance of the survival rate and shoot height of Eucalyptus seedlings at 45 days.

\begin{tabular}{lccc}
\hline \multirow{2}{*}{ Variation source } & DF & \multicolumn{2}{c}{ Mean square } \\
\hline Block & 3 & 41.40 & SH \\
C & 1 & $17.40^{\mathrm{ns}}$ & 1.888 \\
S & 3 & $32.20^{\mathrm{ns}}$ & $0.078^{\mathrm{ns}}$ \\
LR & 1 & $0.70^{\mathrm{ns}}$ & $23.801^{*}$ \\
C $\times$ S & 3 & $43.30^{\mathrm{ns}}$ & $0.204^{\mathrm{ns}}$ \\
C $\times$ LR & 1 & $84.00^{*}$ & $3.437^{\mathrm{ns}}$ \\
S $\times$ LR & 3 & $19.20^{\mathrm{ns}}$ & $1.566^{\mathrm{ns}}$ \\
C $\times$ S $\times$ LR & 3 & $24.80^{\mathrm{ns}}$ & $1.955^{\mathrm{ns}}$ \\
Residue & 45 & 20.20 & 1.288 \\
CV & $\%$ exp & 4.70 & 12.40 \\
Mean & & 96.15 & 9.18 \\
\hline C
\end{tabular}

C: clone; S: mini-cuttings size; LR: leaf reduction; $\mathrm{CV}_{\text {exp }}$ : experimental coefficient of variation \%; $\mathrm{SH}$ : shoot height, $\mathrm{cm}$; SR: survival rate \%; ${ }^{*}$ significant at $5 \%$; ns: not significant at $5 \%$ probability.

TABLE 2: Average results of significant interactions related to the size of the apical mini-cuttings for the seedlings at 45 days.

\begin{tabular}{lcccc}
\hline \multirow{2}{*}{ Variable } & \multicolumn{4}{c}{ Sizes of apical mini-cuttings $(\mathrm{cm})$} \\
& 4 & 6 & 8 & 10 \\
\hline $\mathrm{SH}(\mathrm{cm})$ & $7.50 \mathrm{~b}$ & $8.45 \mathrm{~b}$ & $9.90 \mathrm{a}$ & $10.87 \mathrm{a}$ \\
\hline
\end{tabular}

SH: shoot height; means followed by the same letter in a row do not differ significantly by Tukey's test at $5 \%$ probability; adjusted equation: $\mathrm{SH}(\mathrm{cm})=$ $5.13623^{*}+0.577305^{*} S(\mathrm{~cm}) R^{2}=0.5092\left({ }^{*} P<0.050\right)$.

After 90 days, $70 \%$ of the evaluated variables showed significant effects for the clones (Tables 3 and 4), and the analysis of the means is shown in Table 5 . The LR treatment was significant for only three variables: the values with and without leaf reduction were 29.7 and 28.2 for $\mathrm{SH}, 1.1$, and 1.0 for SDM and 52.7 and 56.6 for B, respectively (Tables 3 and 4). Despite the significant difference observed for the LR treatment, in practical terms, the values were nearly equal; that is, the differences in growth showed no practical significance when considering seedling planting under a regular field condition.

A triple interaction was observed only for $\mathrm{N}$ and $\mathrm{Zn}$ (Tables 3 and 4). However, the consequences of these effects are not relevant, as the average values of these nutrients observed for the two clones were observed to be within the reference limits for the proper development of Eucalyptus seedlings. Thus, there is no practical effect of conducting such segregation.

The contents of the macro- and micronutrients for both clones, in general, were not influenced by the size of the minicuttings or the reduction of leaf area (Table 5).

The process of reducing leaf area, a process evaluated in this study, is a procedure inherited from the time when companies worked with seedlings from macrocuttings produced from field clonal hedges. At that time, reducing the leaf area was very important because the leaf cuttings had much larger areas than those of apical minicuttings. Consequently, the potential loss of water was higher, and the potential for root formation was lower and had to be induced by the use of hormones. With the development of techniques to produce minicuttings from miniclonal hedges, the clonal nurseries started using smaller leaves than those of macrocuttings; with a lower ontogenetic age, this material was more capable of producing roots [15]. Another likely contributing factor explaining the positive effect of the leaf area in the present study is the current quality of the nebulization systems, which are intended to maintain a high-humidity environment to reduce the vapor pressure deficit, thereby reducing evapotranspiration. Thus, the dehydration and death of the cuttings before the period required for rooting were avoided or reduced.

The positive response of not reducing the leaf area corroborates the results of Santana et al. [4], and the positive response of the size of the cuttings is in agreement with Alfenas et al. [2], who noted that the use of vegetative propagules between 4 and $8 \mathrm{~cm}$ is suitable for the production of Eucalyptus seedlings by minicuttings. However, the present study does not confirm the need to reduce the leaf area, as discussed by Alfenas et al. [2] and Xavier et al. [3], as a standard procedure in the process of preparing minicuttings. In addition, not reducing the leaf area decreases the labor and costs of producing seedlings, as it eliminates this operation and reduces repetitive-stress injuries to the workers, a common issue associated with this activity.

According to Gomes et al. [10], the best parameters for estimating the survival rate and early growth of seedlings in the field are the SDM, RDM, SH/SBD, SH/SDM, SDM/RDM, and DQI. In general, there was no significant variation in most of these variables for the clones (Table 5). In the cases of major change, the lowest values are similar to those observed by other authors [4] in seedlings considered suitable for planting.

In their quality controls, forestry companies consider that seedlings with average heights between 15 and $30 \mathrm{~cm}$ with a stem base diameter greater than $2 \mathrm{~mm}$ are suitable for field planting [10], as the differences observed in seedlings tend to disappear with the age of the plant. Thus, when analyzing the seedlings at 90 days (Table 5), it was observed that both clones had already achieved these criteria, and consequently, they were expected to develop well in the field.

Another essential characteristic for evaluating the production of seedlings is their survival rate, that is, when they are ready for transplanting. The observed value of $94.6 \%$ (Table 5) demonstrates that both the clones and the treatment resulted in a very high survival rate. Under normal operating conditions in nurseries, the usual losses are above 20\%; thus, the $5 \%$ acceptability level established by quality control is a challenging goal. The present results demonstrate that the production process was well developed and that the treatment did not negatively affect the development of the seedlings.

Monitoring the nutritional status of the seedlings by the leaf nutrient contents is important to ascertain whether the treatments influenced the nutritional status of the plants. 
TABLE 3: Summary of the analysis of variance for the variables analyzed at 90 days.

\begin{tabular}{|c|c|c|c|c|c|c|}
\hline \multirow{2}{*}{ Variation source } & \multirow{2}{*}{$\mathrm{DF}$} & \multicolumn{5}{|c|}{ Mean square } \\
\hline & & SR & $\mathrm{SH}$ & SDM & $\mathrm{RDM}$ & $\mathrm{SH} / \mathrm{SBD}$ \\
\hline Block & 3 & 3.2 & 15.01 & 0.01572 & 0.00058 & 9.019 \\
\hline C & 1 & $3.6^{\mathrm{ns}}$ & $448.81^{* *}$ & $0.22048^{* *}$ & $0.02323^{*}$ & $114.017^{*}$ \\
\hline S & 3 & $27.3^{\mathrm{ns}}$ & $7.81^{\mathrm{ns}}$ & $0.02948^{\mathrm{ns}}$ & $0.02320^{* *}$ & $2.136^{\mathrm{ns}}$ \\
\hline LR & 1 & $17.4^{\mathrm{ns}}$ & $33.18^{*}$ & $0.05683^{*}$ & $0.00147^{\mathrm{ns}}$ & $0.991^{\mathrm{ns}}$ \\
\hline $\mathrm{C} \times \mathrm{S}$ & 3 & $0.9^{\mathrm{ns}}$ & $8.97^{\mathrm{ns}}$ & $0.01577^{\mathrm{ns}}$ & $0.00116^{\mathrm{ns}}$ & $0.560^{\mathrm{ns}}$ \\
\hline $\mathrm{C} \times \mathrm{LR}$ & 1 & $7.0^{\mathrm{ns}}$ & $1.96^{\mathrm{ns}}$ & $0.00852^{\mathrm{ns}}$ & $0.00197^{\mathrm{ns}}$ & $1.569^{\mathrm{ns}}$ \\
\hline$S \times L R$ & 3 & $4.0^{\mathrm{ns}}$ & $7.13^{\mathrm{ns}}$ & $0.01720^{\mathrm{ns}}$ & $0.00268^{\mathrm{ns}}$ & $0.901^{\mathrm{ns}}$ \\
\hline $\mathrm{C} \times \mathrm{S} \times \mathrm{LR}$ & 3 & $6.6^{\mathrm{ns}}$ & $2.75^{\mathrm{ns}}$ & $0.00463^{\mathrm{ns}}$ & $0.01188^{\mathrm{ns}}$ & $0.696^{\mathrm{ns}}$ \\
\hline Residue & 45 & 21.4 & 4.92 & 0.01296 & 0.00058 & 0.843 \\
\hline \multirow[t]{2}{*}{$\mathrm{CV}_{\exp } \%$} & & 4.9 & 7.7 & 10.6 & 5.4 & 9.1 \\
\hline & & SH/SDM & SDM/RDM & DQI & SBD & $\mathrm{N}$ \\
\hline Block & 3 & 0.78 & 0.0291 & 0.000865 & 1.1889 & 0.0536 \\
\hline C & 1 & $1067.43^{* *}$ & $0.0361^{\mathrm{ns}}$ & $0.022610^{*}$ & $0.8351^{*}$ & $0.0900^{* *}$ \\
\hline S & 3 & $15.14^{\mathrm{ns}}$ & $0.2232^{\mathrm{ns}}$ & $0.000239^{\mathrm{ns}}$ & $0.0385^{\mathrm{ns}}$ & $0.0231^{* *}$ \\
\hline LR & 1 & $2.25^{\mathrm{ns}}$ & $0.1112^{\text {ns }}$ & $0.000013^{\mathrm{ns}}$ & $0.0343^{\mathrm{ns}}$ & $0.0089^{\mathrm{ns}}$ \\
\hline $\mathrm{C} \times \mathrm{S}$ & 3 & $25.11^{\mathrm{ns}}$ & $0.1229^{\mathrm{ns}}$ & $0.000221^{\mathrm{ns}}$ & $0.0239^{\mathrm{ns}}$ & $0.0031^{\mathrm{ns}}$ \\
\hline $\mathrm{C} \times \mathrm{LR}$ & 1 & $26.99^{\mathrm{ns}}$ & $0.0617^{\mathrm{ns}}$ & $0.000182^{\mathrm{ns}}$ & $0.0645^{\mathrm{ns}}$ & $0.0139^{\mathrm{ns}}$ \\
\hline $\mathrm{S} \times \mathrm{LR}$ & 3 & $4.64^{\mathrm{ns}}$ & $0.0151^{\mathrm{ns}}$ & $0.000091^{\mathrm{ns}}$ & $0.0711^{\mathrm{ns}}$ & $0.0084^{\mathrm{ns}}$ \\
\hline $\mathrm{C} \times \mathrm{S} \times \mathrm{LR}$ & 3 & $9.45^{\mathrm{ns}}$ & $0.4287^{\mathrm{ns}}$ & $0.000046^{\mathrm{ns}}$ & $0.0213^{\mathrm{ns}}$ & $0.0486^{* *}$ \\
\hline Residue & 45 & 0.78 & 0.1531 & 0.000303 & 0.0518 & 0.0170 \\
\hline \multirow[t]{2}{*}{$\mathrm{CV}_{\exp } \%$} & & 3.2 & 15.9 & 14.0 & 7.8 & 10.1 \\
\hline & & $\mathrm{P}$ & $\mathrm{K}$ & $\mathrm{Ca}$ & $\mathrm{Mg}$ & $\mathrm{S}$ \\
\hline Block & 3 & 0.009672 & 0.39692 & 0.03491 & 0.002336 & 0.001392 \\
\hline $\mathrm{C}$ & 1 & $0.000074^{\mathrm{ns}}$ & $0.05470^{\mathrm{ns}}$ & $0.36255^{* *}$ & $0.000068^{\mathrm{ns}}$ & $0.014310^{* *}$ \\
\hline S & 3 & $0.000217^{\mathrm{ns}}$ & $0.00503^{\mathrm{ns}}$ & $0.00437^{\mathrm{ns}}$ & $0.000241^{\mathrm{ns}}$ & $0.000265^{\mathrm{ns}}$ \\
\hline LR & 1 & $0.000125^{\mathrm{ns}}$ & $0.00365^{\mathrm{ns}}$ & $0.00195^{\mathrm{ns}}$ & $0.000023^{\mathrm{ns}}$ & $0.000054^{\mathrm{ns}}$ \\
\hline $\mathrm{C} \times \mathrm{S}$ & 3 & $0.000737^{\mathrm{ns}}$ & $0.02062^{\mathrm{ns}}$ & $0.00034^{\mathrm{ns}}$ & $0.000126^{\mathrm{ns}}$ & $0.000064^{\mathrm{ns}}$ \\
\hline $\mathrm{C} \times \mathrm{LR}$ & 1 & $0.001287^{\mathrm{ns}}$ & $0.01648^{\mathrm{ns}}$ & $0.00103^{\mathrm{ns}}$ & $0.000011^{\mathrm{ns}}$ & $0.000001^{\mathrm{ns}}$ \\
\hline$S \times L R$ & 3 & $0.000191^{\mathrm{ns}}$ & $0.00820^{\mathrm{ns}}$ & $0.00375^{\mathrm{ns}}$ & $0.000039^{\mathrm{ns}}$ & $0.000217^{\mathrm{ns}}$ \\
\hline $\mathrm{C} \times \mathrm{S} \times \mathrm{LR}$ & 3 & $0.000060^{\mathrm{ns}}$ & $0.00169^{\mathrm{ns}}$ & $0.00363^{\mathrm{ns}}$ & $0.000161^{\mathrm{ns}}$ & $0.000040^{\mathrm{ns}}$ \\
\hline Residue & 45 & 0.000510 & 0.01869 & 0.00416 & 0.000388 & 0.000398 \\
\hline $\mathrm{CV}_{\exp } \%$ & & 11.3 & 12.1 & 7.6 & 6.3 & 14.0 \\
\hline
\end{tabular}

C: clone; S: mini-cuttings size; LR: leaf reduction; $\mathrm{CV}_{\text {exp }}$ : experimental coefficient of variation $\% ;{ }^{* *}$ significant at $1 \%,{ }^{*}$ significant at $5 \%$ probability; $\mathrm{SR}$ : survival rate \%; SH: shoot height in cm; SDM: shoot dry matter in g/plant; RDM: root dry matter in g/plant; SBD: stem base diameter in mm; DQI: Dickson quality index; macronutrients: $\mathrm{N}, \mathrm{P}, \mathrm{K}, \mathrm{Ca}, \mathrm{Mg}$, and $\mathrm{S}$.

The leaf concentrations for all of the macro- and micronutrients are within the range of the expected values [9] (Table 5). A better nutritional status in the leaf is important for root formation and plant growth, as has been well documented in the literature $[6,16]$. Nutrition is the key factor affecting rooting because of its involvement in determining the morphogenetic response of the plants, and the success rate of vegetative propagation programs depends on the optimal plant nutrient status, which is important for initial growth under field conditions [17]. The treatments of the present study did not affect the development of the seedlings. Therefore, the nonreduction of leaf area is both technically and economically viable because it is not necessary to spend time on leaf reduction activity, which results in loss of operational efficiency and increases the risk of repetitive-stress disorders in the workers.

\section{Conclusions}

The length of the minicuttings and the reduction of leaf area did not affect the nutritional status of the leaves, nor did the length affect the quality of the plants at the age of 90 days. It is unnecessary to reduce the leaf area for Eucalyptus propagation. 
TABLE 4: Summary of the analysis of variance for the variables analyzed at 90 days.

\begin{tabular}{|c|c|c|c|c|c|c|}
\hline \multirow{2}{*}{ Variation source } & \multirow{2}{*}{ DF } & \multicolumn{5}{|c|}{ Mean square } \\
\hline & & $\mathrm{Zn}$ & $\mathrm{Fe}$ & $\mathrm{Mn}$ & $\mathrm{Cu}$ & $\mathrm{B}$ \\
\hline Block & 3 & 262.88 & 3131.1 & 6101 & 0.786 & 206.4 \\
\hline C & 1 & $623.69^{* *}$ & $3896.9^{*}$ & $12106^{* *}$ & $0.090^{\mathrm{ns}}$ & $424.4^{* *}$ \\
\hline$S$ & 3 & $50.35^{\mathrm{ns}}$ & $376.1^{\mathrm{ns}}$ & $162^{\mathrm{ns}}$ & $0.939^{\text {ns }}$ & $46.9^{\mathrm{ns}}$ \\
\hline LR & 1 & $59.27^{\mathrm{ns}}$ & $1417.5^{\mathrm{ns}}$ & $7064^{\mathrm{ns}}$ & $0.302^{\mathrm{ns}}$ & $241.8^{*}$ \\
\hline $\mathrm{C} \times \mathrm{S}$ & 3 & $231.16^{* *}$ & $201.8^{\text {ns }}$ & $1785^{\mathrm{ns}}$ & $0.630^{\mathrm{ns}}$ & $6.4^{\mathrm{ns}}$ \\
\hline$C \times L R$ & 1 & $186.29^{*}$ & $49.4^{\mathrm{ns}}$ & $365^{\mathrm{ns}}$ & $0.181^{\text {ns }}$ & $5.2^{\mathrm{ns}}$ \\
\hline $\mathrm{S} \times \mathrm{LR}$ & 3 & $0.63^{\mathrm{ns}}$ & $295.2^{\mathrm{ns}}$ & $782^{\text {ns }}$ & $0.552^{\text {ns }}$ & $14.2^{\mathrm{ns}}$ \\
\hline $\mathrm{C} \times \mathrm{S} \times \mathrm{LR}$ & 3 & $118.96^{*}$ & $710.1^{\mathrm{ns}}$ & $2660^{\mathrm{ns}}$ & $0.218^{\mathrm{ns}}$ & $2.4^{\mathrm{ns}}$ \\
\hline Residue & 45 & 36.67 & 397.1 & 1531 & 0.464 & 33.5 \\
\hline $\mathrm{CV}_{\exp } \%$ & & 18.0 & 21.3 & 9.0 & 12.7 & 10.6 \\
\hline
\end{tabular}

C: clone; S: mini-cuttings size; LR: leaf reduction; $\mathrm{CV}_{\text {exp }}$ : experimental coefficient of variation $\% ;{ }^{* *}$ significant at $1 \%$, ${ }^{*}$ significant at $5 \%$ probability; micronutrients: $\mathrm{Zn}, \mathrm{Fe}, \mathrm{Mn}, \mathrm{Cu}$, and B.

TABLE 5: Average results for the variables analyzed at 90 days.

\begin{tabular}{|c|c|c|c|c|c|c|c|c|}
\hline & \multicolumn{8}{|c|}{ Variables } \\
\hline & SR & $\mathrm{SH}$ & SDM & $\mathrm{RDM}$ & $\mathrm{SH} / \mathrm{SBD}$ & $\mathrm{SH} / \mathrm{SDM}$ & SDM/RDM & DQI \\
\hline $\mathrm{Cl}$ & - & $31.6 \mathrm{a}$ & $1.01 \mathrm{~b}$ & $0.42 \mathrm{~b}$ & $11.4 \mathrm{a}$ & $31.6 \mathrm{a}$ & - & $0.11 \mathrm{~b}$ \\
\hline $\mathrm{C} 2$ & - & $26.3 \mathrm{~b}$ & $1.13 \mathrm{a}$ & $0.46 \mathrm{a}$ & $8.7 \mathrm{~b}$ & $23.5 \mathrm{~b}$ & - & $0.14 \mathrm{a}$ \\
\hline \multirow[t]{2}{*}{ Mean } & 94.6 & - & - & - & - & - & 2.47 & - \\
\hline & SBD & $\mathrm{N}$ & $\mathrm{P}$ & $\mathrm{K}$ & $\mathrm{Ca}$ & $\mathrm{Mg}$ & S & $\mathrm{Zn}$ \\
\hline $\mathrm{Cl}$ & $2.81 \mathrm{~b}$ & $1.33 \mathrm{a}$ & - & - & $0.78 \mathrm{~b}$ & - & $0.13 \mathrm{a}$ & $36.8 \mathrm{a}$ \\
\hline $\mathrm{C} 2$ & $3.04 \mathrm{a}$ & $1.26 \mathrm{~b}$ & - & - & $0.93 \mathrm{a}$ & - & $0.16 \mathrm{~b}$ & $30.6 \mathrm{~b}$ \\
\hline Mean & - & - & 0.20 & 1.13 & - & 0.31 & - & - \\
\hline \multirow[t]{2}{*}{$\mathrm{RV}$} & - & $1.3-1.5$ & $0.15-0.20$ & $1.5-2.0$ & $0.8-1.2$ & $0.30-0.35$ & $0.13-0.15$ & $30-40$ \\
\hline & $\mathrm{Fe}$ & $\mathrm{Mn}$ & $\mathrm{Cu}$ & B & & & & \\
\hline $\mathrm{Cl}$ & $101.3 \mathrm{a}$ & $422.2 \mathrm{~b}$ & - & $52.0 \mathrm{~b}$ & & & & \\
\hline $\mathrm{C} 2$ & $85.7 \mathrm{~b}$ & $449.7 \mathrm{a}$ & - & $57.2 \mathrm{a}$ & & & & \\
\hline Mean & - & - & 5.3 & - & & & & \\
\hline $\mathrm{RV}$ & $80-130$ & $300-500$ & $10-15$ & $30-40$ & & & & \\
\hline
\end{tabular}

Means followed by the same letter in a column do not differ significantly by $F$ test at $5 \%$ probability. C: clone; SR: survival rate \%; SH: shoot height in cm; SDM: shoot dry matter in g/plant; RDM: root dry matter in g/plant; SBD: stem base diameter in mm; DQI: Dickson quality index; macronutrients (dag/kg): N, P, K, $\mathrm{Ca}, \mathrm{Mg}$, and S; micronutrients (mg/kg): Zn, Fe, Mn, Cu, and B; RV: reference values for seedlings between 80 and 100 days (Silveira et al., 2001 [9]).

\section{Acknowledgment}

The authors acknowledge the effort of Plantar Reforestation Co., for making this research possible by providing financial support, personnel, and infrastructure.

\section{References}

[1] T. F. Assis, A. G. Fett-Neto, and A. C. Alfenas, "Current technics and prospects for the clonal propagation of hardwoods with emphasis on Eucalyptus," in Plantation Forest Biotechnologyfor the 21st Century, C. Walter and M. Carson, Eds., Research Signpost, Kerala, India, 2004.

[2] A. C. Alfenas, E. A. V. Zauza, R. G. Mafia, and T. F. Assis, Clonagem e doenças do Eucalipto, Editora UFV, Viçosa, Brazil, 2009.

[3] A. Xavier, I. Wendling, and R. L. Silva, Silvicultura Clonal: Princípios e Técnicas, Editora UFV, Viçosa, Brazil, 2009.

[4] R. C. Santana, T. R. Dutra, J. P. C. Neto, G. S. Nogueira, P. H. Grazziotti, and N. F. de Barros Filho, "Iinfluence of leaf area reductio on clonal production of eucalyptus seedlings," Cerne, vol. 16, no. 3, pp. 251-257, 2010.

[5] G. A. Couvillon, "Rooting responses to different treatments," Acta Horticulturae, vol. 227, pp. 187-196, 1988.

[6] H. T. Hartmann, D. E. Kester, F. T. Davis-Júnior, and R. L. Geneve, Plant Propagation: Principles and Practices, Englewood Clipps, New York, NY, USA, 7th edition, 2002.

[7] N. P. Lima, L. A. Biasi, F. Zanette, and T. Nakashima, "Produção de mudas por estaquia de duas espécies de guaco," Horticultura Brasileira, vol. 21, no. 1, pp. 106-109, 2003.

[8] O. Reuveni and M. Raviv, "Importance of leaf retention to rooting of avocado cuttings," Journal of the American Society For Horticultural Science, vol. 106, pp. 127-130, 1981.

[9] R. L. V. A. Silveira, E. N. Higashi, F. Sgarb, and M. R. A. Muniz, Seja o Doutor do seu Eucalipto, Potafos, Piracicaba, Brazil, 2001.

[10] J. M. Gomes, L. Couto, H. G. Leite, A. Xavier, and S. L. R. Garcia, "Morphological parameters quality for the evalution of Eucalyptus grandis seedling," Revista Árvore, vol. 26, no. 6, pp. 655-664, 2002. 
[11] E. P. Foneeca, Padrão de qualidade de mudas de Trema mícrantha (L.) Blume., Cedrela fissilis Veli. E Aspidosperma polyneuron Müll Arg. produzidas sob diferentes períodos de sombreamento [Ph.D. thesis], Universidade Estadual Paulista, Jabotical, Brazil, 2000.

[12] Embrapa and Empresa Brasileira de Pesquisa Agropecuária, Manual de métodos de análises químicas de solos, plantas e fertilizantes, Embrapa Comunicação para Transferência de Tecnologia, Brasília, Brazil, 1999.

[13] STATSOFT Inc, "Statistica (data analysis software system)," Version 10 http://www.statsoft.com/, 2011.

[14] W. G. O. Carvalho Júnior, M. T. P. Melo, and E. R. Martins, "Comprimento da estaca no desenvolvimento de mudas de alecrim-pimenta," Ciência Rural, vol. 39, no. 7, pp. 2199-2202, 2009.

[15] I. Wendling and A. Xavier, "Maturation gradient and rejuvenation applied to forestry species," Floresta e Ambiente, vol. 8, pp. 187-194, 2001.

[16] V. Pellicer, J. Guehl, F. Daudet, M. Cazet, L. M. Riviere, and P. Maillard, "Carbon and nitrogen mobilization in Larix $\mathrm{x}$ eurolepis leafy stem cuttings assessed by dual $13_{\mathrm{C}}$ and $15_{\mathrm{N}}$ labeling: relationships with rooting," Tree Physiology, vol. 20, no. 12, pp. 807-814, 2000.

[17] J. Schwambach, C. Fadanelli, and A. G. Fett-Neto, "Mineral nutrition and adventitious rooting in microcuttings of Eucalyptus globulus," Tree Physiology, vol. 25, no. 4, pp. 487-494, 2005. 

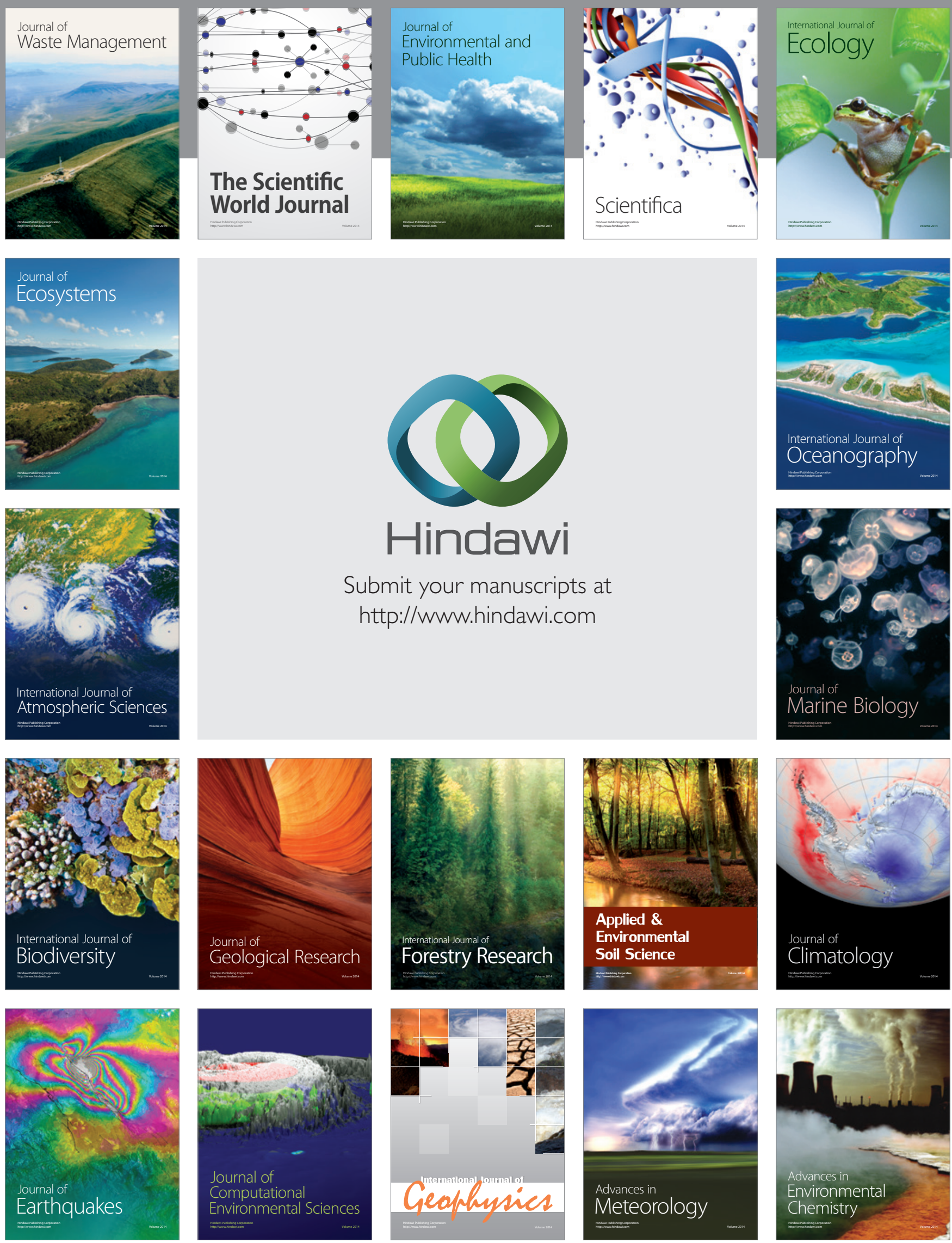